\title{
Study of a Marine Microbial Fuel Cell on a Pilot Scale
}

\author{
G. CHITHRALEKHA ${ }^{\mathrm{a}, \mathrm{b}}$ and SRIKANTH MUTNURI ${ }^{\mathrm{b}}$ \\ ${ }^{a}$ SRM University, Potheri, Kattankulathur, Chennai, Tamilnadu- 603203, India \\ ${ }^{\mathrm{b}}$ Birla Institute of Technology and Science, K. K. Birla Goa campus, National Highway \\ 17B, Zuarinagar, Goa 403726, India \\ clekha91@gmail.com
}

Received 21 January 2013 / Accepted 15 February 2013

\begin{abstract}
Microbial fuel cell (MFC) are potential sources to generate electricity directly by using bacteria and their mechanism of breakdown of organic matter. MFCs can also be used in wastewater treatment facilities to breakdown organic matters. They have also been studied for applications as biosensors such as sensors for biological oxygen demand monitoring. A prototype of MFC using marine sediment making up the anaerobic anode compartment with overlying cathode chamber containing continuously aerated water. The anodic chamber was fed with $200 \mathrm{mM}$ sodium acetate as substrate for the microbial consortium in the sea sediment. Graphite electrodes were used in both the chambers to study the generation of power. A maximum of $0.574 \mathrm{~V}$ was observed in MFC1 \& 2 with distilled water in the cathode chamber and 0.3V was detected in MFC filled with seawater in the cathode compartment. The DNA extracted from the bio films on the electrodes was studied using agarose gel electrophoresis and UV spectroscopy to study the purity and quantity respectively. The amount of DNA obtained from the anode was quantified as $0.510 \mathrm{mg} / \mathrm{mL}$ and no bio film was observed on the cathode. Therefore, the commercialization of marine MFC with a complete understanding of microbial community involved in power generation can pave the way for a potential power source in India, a country with vast coastlines.
\end{abstract}

Keywords: Microbial fuel, Pilot scale, Bioreactor

\section{Introduction}

A microbial fuel cell (MFC) is a bioreactor that converts chemical energy of organic compounds to electrical energy through catalytic reactions of microorganisms under anaerobic conditions ${ }^{1}$. A typical MFC consists of anodic and cathodic chambers partitioned by a proton exchange membrane (PEM). Bacteria can be used in MFCs to generate electricity while accomplishing the biodegradation of organic matters or wastes. Microbes in the anodic chamber of an MFC oxidize added substrates and generate electrons and protons in the process. Carbon dioxide is produced as an oxidation product. The electrons are absorbed by the anode and are transported to the cathode through an external circuit. The overall reaction is the breakdown of the substrate to carbon dioxide and water by the microorganisms with a concomitant production of electricity as a by-product ${ }^{2}$.

The common types of microbial fuel cell include four types namely: One compartment, two compartment, mediator and mediator-free. A one compartment MFC consists of a single chamber with anode at the bottom maintained at anaerobic conditions and cathode at the top

$\uparrow$ Presented to the National Conference on Chemistry Solutions at SRM University, India 
which is aerated. A typical two compartment MFC has an anodic chamber and a cathodic chamber connected by a Proton exchange membrane (PEM), or sometimes a salt bridge, to allow protons to move across to the cathode while blocking the diffusion of oxygen into the anode.

Microbial fuel cells are devices that can produce electrical power in the course of treatment of industrial, agricultural and municipal wastewater. With the aid of microbial fuel cells, various monitors can be powered, e.g., temperature, salinity, tidal patterns, the presence of algae and other life forms, migration patterns of Fish and other marine wildlife, organic contamination from oil production and metallic compounds from other industrial processes ${ }^{3}$. If power generation in these systems can be increased, MFCs may provide a new method to offset operating costs of waste water treatment plants, making advanced waste water treatment more affordable in both developing and industrialized nations ${ }^{4}$. In addition, MFCs are also known to generate less excess sludge as compared to the aerobic treatment process. MFCs can also be employed as biosensors for pollutant analysis and in situ process monitoring and control. MFC sensors have the advantages of excellent operational stability, good reproducibility and accuracy. The objective of this work was to study the performance and microbial community of a marine MFC on a laboratory scale for power generation.

\section{Experimental}

\section{Preparation of marine microbial fuel cell}

Three $1 \mathrm{~L}$ plastic bottles were chosen for setting up the marine microbial fuel cells in the laboratory. Sea sediments were collected from a local beach in Goa and filled the bottom part of bottles forming the anodic chamber. The top portion was filled with distilled water (MFC $1 \& 2$ ) and with seawater (MFC 3) which is continuously aerated and formed the cathode chamber. Graphite electrodes of approx. $12 \mathrm{~cm} \times 4 \mathrm{~cm}$ connected to electrical wires were placed in both the compartments of MFC 1, 2 and 3 used to measure the power generation in the microbial fuel cell. The anodic chamber was provided with $200 \mathrm{mM}$ sodium acetate as substrate for the microbial community and the power generated was measured in volts $(\mathrm{V})$ every 24 hours using a multimeter.

\section{Extraction of DNA from sea sediments}

Approximately $2 \mathrm{~g}$ of sediment was taken from the MFCs and used for DNA extraction by adopting the following methods:

\section{Extraction of DNA from sediment samples ${ }^{5}$}

Sediment sample was suspended in $50 \mu \mathrm{L}$ of solution 1 (Table 1) and was pipetted vigorously to re-suspend the sample. Samples were freeze thawed at $-80{ }^{\circ} \mathrm{C}$ in a deep freezer and then placed at $55^{\circ} \mathrm{C}$ hot block 8-10 times. These steps were performed very quickly with as little time with thawed samples as possible. $200 \mu \mathrm{L}$ of solution $1,100 \mu \mathrm{L}$ of lysozyme $(4 \mathrm{mg} / \mathrm{mL})$ solution and $50 \mu \mathrm{L}$ of $500 \mathrm{mM}$ ethylenediaminetetraacetic acid (EDTA) were added to the thawed sample. Sample was turned for 5-15 minutes (e.g. on a roller apparatus). $50 \mu \mathrm{L} 10 \%$ SDS was added followed quickly by $800 \mu \mathrm{L}$ phenol-chloroform (> pH 7.0) and the tube was vortexed for 1-2 minutes to form an emulsion. The tube was centrifuged at maximum speed $(\sim 16,000 \times \mathrm{g})$ for 3 minutes. Top (aqueous) phase was carefully pipette out, avoiding lower phases and any solids (if present) and added to a new centrifuge tube with $800 \mu \mathrm{L}$ of phenolchloroform already added. The tube was vortexed for 1 minute at maximum speed, then spun in centrifuge for 3 minutes. Top layer was removed and added to a new micro-centrifuge tube. Glycogen was added as carrier. The DNA was precipitated by adding $50 \mu \mathrm{L}$ of $3.0 \mathrm{M}$ 
sodium acetate and $1000 \mu \mathrm{L}$ of $100 \%$ ethanol. The tube was centrifuged at $12000 \mathrm{~g}$ speed for 15 minutes at $4{ }^{\circ} \mathrm{C}$. The supernatant was discarded and the pellet was suspended in sterile water or TE buffer.

Table 1. Composition of solution 1 used for DNA extraction from sediment samples by Lee method $^{5}$

\begin{tabular}{cc}
\hline Solution 1 & Volume of stock solution, $100 \mathrm{~mL}$ \\
\hline $50 \mathrm{mM}$ glucose & $2.3 \mathrm{~mL} 40 \%$ glucose \\
$10 \mathrm{mM}$ EDTA & $2 \mathrm{~mL} \mathrm{500} \mathrm{mM} \mathrm{EDTA}$ \\
$25 \mathrm{mM}$ Tris-Cl (pH 8.0) & $2.5 \mathrm{~mL} 1 \mathrm{M}$ Tris \\
Double distilled water & $93.2 \mathrm{~mL}$ \\
\hline
\end{tabular}

\section{Glass bead-beating $(G B)$ method $^{6}$}

Two grams of sediment sample (wet weight) was suspended in $500 \mu \mathrm{L}$ of lysis buffer $(0.1 \mathrm{M}$ Tris- $\mathrm{HCl}$ [pH 8.0], 0.1 M EDTA [pH 8.0], $0.1 \mathrm{M} \mathrm{NaCl}, 0.2 \%$ hexadecyltrimethylammonium bromide $[\mathrm{CTAB}][\mathrm{w} / \mathrm{v}])$ in a $10 \mathrm{~mL}$ centrifuge tube and an equal weight of glass beads was added. The tube was vortexed vigorously for $60 \mathrm{~s}$ and then centrifuged at $8000 \mathrm{~g}$ for $15 \mathrm{~min}$ at $4{ }^{\circ} \mathrm{C}$ in a centrifuge. The supernatant was transferred to a fresh tube and extracted by the equal volume of phenol/chloroform $(1: 1, \mathrm{v} / \mathrm{v})$. The upper aqueous phase was added $1 / 10$ volume of $3 \mathrm{M}$ sodium acetate ( $\mathrm{pH}$ 5.2) and 2.5 volumes of ethanol and precipitated at $-20{ }^{\circ} \mathrm{C}$ for $30 \mathrm{~min}$. Then the tube was centrifuged at $8000 \mathrm{~g}$ for $15 \mathrm{~min}$ at $4{ }^{\circ} \mathrm{C}$. The supernatant was removed and the pellet was rinsed with $500 \mu \mathrm{L}$ of $70 \%$ ethanol (v/v). The tube was centrifuged at $8000 \mathrm{~g}$ for $15 \mathrm{~min}$ at $4{ }^{\circ} \mathrm{C}$. The supernatant was removed and the pellet was allowed to dry in the air for $15 \mathrm{~min}$. The pellet was dissolved in $50 \mu \mathrm{L}$ of TE $\left(\mathrm{pH}\right.$ 8.0) and the DNA solution was stored at $-20{ }^{\circ} \mathrm{C}$.

\section{Enzymatic lysis (EL) method ${ }^{6}$}

Two grams of sediment sample (wet weight) were suspended in $1.4 \mathrm{~mL}$ of extraction buffer (0.1 M Tris- $\mathrm{HCl}[\mathrm{pH} 8.0], 0.1 \mathrm{M}$ EDTA [pH 8.0], $1.5 \mathrm{M}$ sodium chloride, 1\% CTAB [w/v]) in a $10 \mathrm{~mL}$ centrifuge tube. The tube was vortexed vigorously for $5 \mathrm{~min}$ and then $20 \mu \mathrm{L}$ of lysozyme solution $(50 \mathrm{mg} / \mathrm{mL})$ and $5 \mu \mathrm{L}$ of protease $\mathrm{K}$ solution $(10 \mathrm{mg} / \mathrm{mL})$ were added to the tube. The tube was incubated at $37^{\circ} \mathrm{C}$ for $30 \mathrm{~min}$. Then $100 \mu \mathrm{L}$ of $20 \%$ SDS (w/v) was added and the tube was incubated at $65^{\circ} \mathrm{C}$ for $2 \mathrm{~h}$.

The tube was centrifuged at $8000 \mathrm{~g}$ for $15 \mathrm{~min}$ at $4{ }^{\circ} \mathrm{C}$ in a centrifuge. The supernatant was transferred to a fresh tube and was extracted by an equal volume of chloroform. The upper aqueous phase was transferred to a fresh tube and 0.6-1.0 volume of isopropanol was added. The tube was incubated at room temperature for $30 \mathrm{~min}$.

The tube was then centrifuged at $8000 \mathrm{~g}$ for $15 \mathrm{~min}$ at $4{ }^{\circ} \mathrm{C}$. The pellet was rinsed with $500 \mu \mathrm{L}$ of $70 \%$ ethanol (v/v) and the tube was centrifuged at $8000 \mathrm{~g}$ for $15 \mathrm{~min}$ at $4{ }^{\circ} \mathrm{C}$. The supernatant was removed and the pellet was allowed to dry in the air for $15 \mathrm{~min}$. The pellet was dissolved in $50 \mu \mathrm{L}$ of $\mathrm{TE}(\mathrm{pH} 8.0)$ and the DNA solution was stored at $-20^{\circ} \mathrm{C}$.

\section{Chemical lysis (CL) method ${ }^{6}$}

Two grams of sediment sample (wet weight) were suspended in $1 \mathrm{~mL}$ of $0.5 \mathrm{M} \mathrm{NaH}_{2} \mathrm{PO}_{4}$ (pH 8.0), $1.4 \mathrm{~mL}$ of lysis solution, $3 \mathrm{M} \mathrm{NaCl}, 0.2 \mathrm{M}$ Tris-HCl, 0.2 M EDTA, (pH 8.0) in a $10 \mathrm{~mL}$ centrifuge tube and $0.5 \mathrm{~mL}$ of $12 \% \mathrm{SDS}(\mathrm{w} / \mathrm{v})$ was added. The tube was incubated at 
$65^{\circ} \mathrm{C}$ for $30 \mathrm{~min}$ and inverted up and down every $15 \mathrm{~min}$. The mixture was extracted with an equal volume of chloroform. The upper aqueous phase was transferred to a fresh tube and $1 / 10^{\text {th }}$ volume of $3 \mathrm{M} \mathrm{NaAc}(\mathrm{pH}$ 5.2) and 2.5 volumes of ethanol was added. The tube was incubated at $20{ }^{\circ} \mathrm{C}$ for $30 \mathrm{~min}$.

Then the tube was centrifuged at $8000 \mathrm{~g}$ for $15 \mathrm{~min}$ at $4{ }^{\circ} \mathrm{C}$ in a centrifuge. The pellet was rinsed with $500 \mu \mathrm{L}$ of $70 \%$ ethanol (v/v) and the tube was centrifuged at $8000 \mathrm{~g}$ for $15 \mathrm{~min}$ at $4{ }^{\circ} \mathrm{C}$. The supernatant was removed and the pellet was allowed to dry in the air for $15 \mathrm{~min}$. The pellet was dissolved in $50 \mu \mathrm{L}$ of TE (pH 8.0) and the DNA solution was stored at $20^{\circ} \mathrm{C}$.

\section{DNA extraction from biofilm on the electrodes ${ }^{7}$}

The extraction of DNA from the bio film was performed by adopting the following method:

1. The biofilm was scraped off the electrodes using a sterile blade into a $2 \mathrm{~mL}$ eppendorf tube.

2. To the tube $750 \mu \mathrm{L}$ of TNE (Tris-HCl,NaCl,EDTA) buffer and $20 \mu \mathrm{L}$ of lysozyme $(50 \mathrm{mg} / \mathrm{mL})$ was added.

3. The tube was incubated at room temperature for 10 minutes.

4. $10 \%$ SDS $(100 \mu \mathrm{L})$, sarkosyl $10 \%(100 \mu \mathrm{L})$ and $100 \mu \mathrm{L}$ of proteinase $\mathrm{K}(10 \mathrm{mg} / \mathrm{mL})$ was added.

5. The tube was incubated for 1 hour at $50{ }^{\circ} \mathrm{C}$.

6. The mixture was extracted using 1 volume of phenol:chloroform:isoamyl alcohol $(25: 24: 1)$.

7. The tube was centrifuged at $8000 \mathrm{~g}$ for 15 minutes at $4{ }^{\circ} \mathrm{C}$.

8. The mixture was extracted using 1 volume of chloroform:isoamyl alcohol(24:1)

9. The tube was centrifuged at $8000 \mathrm{~g}$ for 15 minutes at $4{ }^{\circ} \mathrm{C}$.

10. The DNA was precipitated out by adding 0.7 volume of isopropanol and incubated overnight at $-20{ }^{\circ} \mathrm{C}$

11. The tube was centrifuged at $8000 \mathrm{~g}$ at $4{ }^{\circ} \mathrm{C}$ for 30 minutes

12. The pellet was rinsed with $70 \%$ ethanol and was allowed to air-dry for 15 minutes and suspended in $50 \mu \mathrm{L}$ sterile TE (10:0.1) buffer.

Determination of DNA quantity and purity

The quantity of DNA was checked by measuring the optical density at $260 \mathrm{~nm}$ in a UV spectrophotometer and the purity and size were measured by performing agarose gel electrophoresis.

\section{Polymerase chain reaction}

Polymerase chain reaction of the extracted DNA was carried out using the primers $27 \mathrm{~F}\left(5^{\prime}\right.$ AGAGTTTGATCMTGGCTCAG) and 1492R (GGTTACCTTGTTACGACTT) and the PCR master mix contained the following composition (Table 2).

Table 2. Composition of PCR reaction master mix

\begin{tabular}{ccc}
\hline Reagents & Quantity $(1 \mathrm{X}) \mu \mathrm{L}$ & Quantity $(3 \mathrm{X}) \mu \mathrm{L}$ \\
Taq buffer & 5 & 15 \\
\hline $\mathrm{MgCl}_{2}$ & 5 & 15 \\
dNTPs & 5 & 15 \\
Forward primer & 0.5 & 1.5 \\
Reverse primer & 0.5 & 1.5 \\
Taq pol. buffer & 0.6 & 1.8 \\
Sterile dist. $\mathrm{H}_{2} \mathrm{O}$ & 30.4 & 91.2 \\
\hline
\end{tabular}


The PCR conditions: Denaturation $-90{ }^{\circ} \mathrm{C}$ for 30 seconds, Annealing $-55{ }^{\circ} \mathrm{C}$ for 30 seconds, Extension $-72{ }^{\circ} \mathrm{C}$ for 45 seconds, Final extension $-72{ }^{\circ} \mathrm{C}$ for 30 minutes were maintained for 25 cycles.

\section{Results and Discussion}

\section{Power generation from the MFCs}

Table 3 shows the power generated from microbial fuel cells (1, 2 and 3) measured by a multimeter on a 24-hour basis. Figure 1 depicts the power generated in volts (V) from the 3 MFCs.

Table 3. Power generated in volts from MFCs 1, 2 and 3

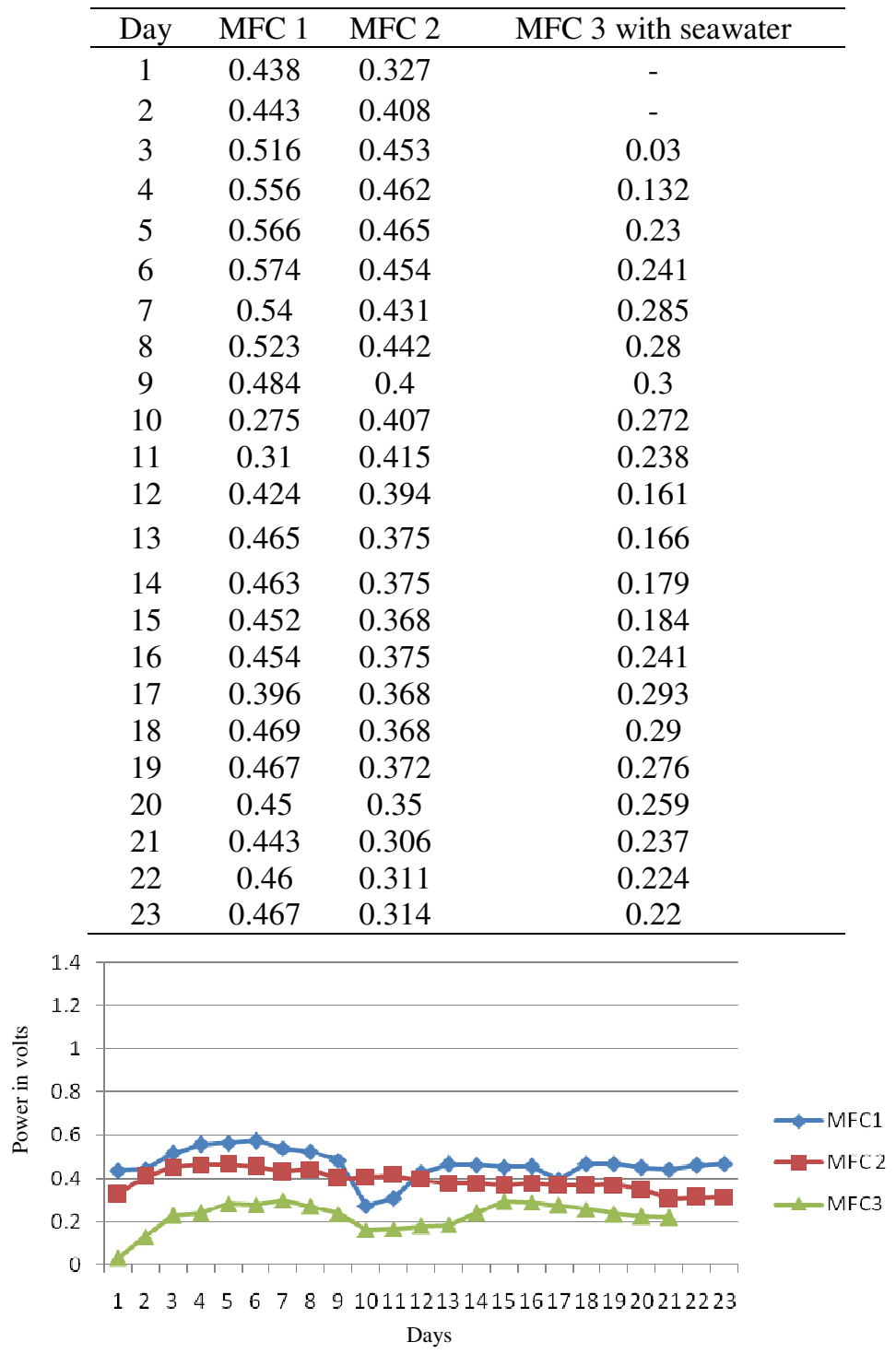

Figure 1. Power generated from MFCs 1, 2 and 3 in volts 


\section{DNA isolation from marine sediments}

No quantifiable amount of DNA was obtained from sea sediments by adopting the methods. The possible reason may be lack of appropriate physical shearing apparatus to separate the microbial cells from the soil particles (Bead mill, Homogeniser etc.) and also unsuitability of the employed DNA extraction methods for the collected marine sediment.

\section{DNA extraction from bio film on the electrodes}

The extracted DNA from the bio films were studied for quantity and purity by agarose gel electrophoresis and UV spectroscopy respectively. The DNA from anode was quantified as $0.510 \mathrm{mg} / \mathrm{mL}$ by calculating the optical density at $260 \mathrm{~nm}$. The isolated DNA was carried out electrophoresis on a $0.7 \%$ agarose gel at $70 \mathrm{~V}$ for $1 \frac{1}{2}$ to $2 \mathrm{~h}$ and is shown in Figure 2. Faint bands of DNA from anode around $1.5 \mathrm{~kb}$ were obtained and no bands were observed for the DNA form the cathode.

\section{Polymerase chain reaction $(P C R)$}

The extracted DNA was subjected to PCR using universal primers $27 \mathrm{~F}$ and $1492 \mathrm{R}$ for amplification of DNA from the electrodes and the results are shown in Figure 3.

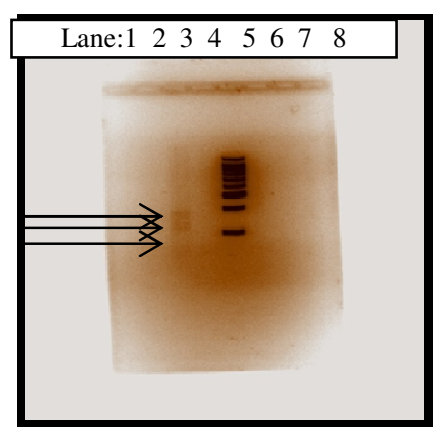

Figure 2. Agarose gel of DNA extracted from bio film

Lane 2: Cathode DNA,

Lane 3: Anode DNA,

Lane 5: $1 \mathrm{~Kb}$ DNA marker

Lane 6: $1 \mathrm{~Kb}$ DNA marker

(Lanes 1,4,7 \& 8 in Figure 2 and Lanes 1,5,6,7,8 in Figure 3 are not loaded with any samples)

PCR product of around $1.5 \mathrm{~kb}$ was obtained for PCR product of bio film DNA extracted from the anode. As expected, no band was observed in the cathode lane.

\section{Conclusion}

This work showed that a pilot-scale marine MFC can generate up to $0.3 \mathrm{~V}$ in a 23-day time period. Also increase in power generation was observed with growth of bio film on the electrode. Hence, microbial fuel cells are a promising sustainable technology source to meet increasing energy and industrial needs. It serves as an economic and conventional source for power generation, wastewater treatment and as biosensors. A complete understanding of the microbial community involved in the production of power will aid in scaling up the process to a commercial scale. Biological energy harvested in the form of electricity from natural and renewable sources have a great development potential to fulfil the growing energy demands and conserve the non-renewable sources of the country. 


\section{References}

1. Du Z, Li H and Gu T, Biotechnol Adv., 2007, 25(5), 464-482.

2. Veeranjaneya Reddy L, Pradeep Kumar S and Young-Jung Wee, Current Research, Technology and Education Topics in Applied Microbiology and Microbial Biotechnology, 2010.

3. Scott K, Cotlarciuc I, Hall D, Lakeman J B and Browninget D, J Appl Electrochem., 2008, 38, 1313-1319.

4. Hongliu L, Ramnarayanan R and Logan B E, Environ Sci Technol., 2004, 38, 2281-2285.

5. Costantino Vetriani, Hiep V Tran and Lee J Kerkhof, Appl Environ Microbiol., 2003, 69(11), 6481-6488; DOI: 10.1128/AEM.69.11.6481-6488.2003

6. Xintian Lai, Xintian Zeng, Xiaofan Fang, Shu Huang, Yali Cao, Lixiang Zhou and Shining, World J Microbiol Biotechnol., 2006, 22(12), 1337-1345.

7. Benjamin Erable, Roncato M-A, Achouak W and Bergel A, Environ Sci Technol., 2009, 43, 3194-3199. 